\title{
Influence of sociodemographic and economic factors on physical activity among university students
}

\section{Influência de fatores sociodemográficos e econômicos na atividade física entre estudantes universitários}

\section{La influencia de factores sociodemográficos y económicos para la actividad física de estudiantes universitarios}

\author{
Suellem Regina Chamberllem (iD \\ Federal University of Mato Grosso (Universidade Federal de Mato Grosso) - Cuiabá (MT) - Brazil
}

Márcia Gonçalves Ferreira (iD

Federal University of Mato Grosso (Universidade Federal de Mato Grosso) - Cuiabá (MT) - Brazil

Paulo Rogério Melo Rodrigues (iD

Federal University of Mato Grosso (Universidade Federal de Mato Grosso) - Cuiabá (MT) - Brazil

Patrícia Simone Nogueira (iD

Federal University of Mato Grosso (Universidade Federal de Mato Grosso) - Cuiabá (MT) - Brazil

Rosângela Alves Pereira iD

Federal University of Rio de Janeiro (Universidade Federal do Rio de Janeiro) - Rio de Janeiro (RJ) - Brazil

Ana Paula Muraro (iD

Federal University of Mato Grosso (Universidade Federal de Mato Grosso) - Cuiabá (MT) - Brazil

\begin{abstract}
Objective: To estimate the influence of socioeconomic factors on the variation in time spent by university students on physical activity after the first academic year. Methods: Quantitative longitudinal study of 348 full-time university students aged 16-25 years from the capital of Mato Grosso, Brazil. Change in time spent on moderate and vigorous physical activity was assessed in minutes per week through the short version of the International Physical Activity Questionnaire (IPAQ). The following independent variables were analyzed: gender, age, race/skin color, economic class, students' housemates and field of study. Multinomial regression analysis was used to check for associations between physical activity time variation in tertiles and the independent variables. Results: The overall change in median physical activity time in one year was -90.0 minutes/week. Students of higher socioeconomic status maintained the same physical activity time, while those in other socioeconomic classes showed a decrease in such time after the first year at university. After adjustments, lower economic class $(\mathrm{OR}=2.85 ; 95 \% \mathrm{Cl}=1.26-6.43)$ and living in a shared house $(\mathrm{OR}=2.84 ; 95 \% \mathrm{Cl}=1.26-6.38)$ were associated with decrease in time spent on physical activity. Conclusion: There was a decrease in time spent on physical activity among students belonging to the lower economic classes who lived in a shared house after the first year at university.
\end{abstract}

Descriptors: Students; Universities; Physical Activity; Longitudinal Studies; Socioeconomics Factors.

\section{RESUMO}

Objetivo: Estimar a influência de fatores socioeconômicos na variação do tempo gasto por estudantes universitários na prática de atividade física após o primeiro ano letivo. Métodos: Estudo quantitativo longitudinal, realizado em 2015 e 2016, com 348 universitários em tempo integral, com idade entre 16 e 25 anos, da capital do Mato Grosso, Brasil. Avaliou-se a mudança no tempo gasto na prática de atividade física moderada e vigorosa em minutos por semana por meio da versão curta do International Physical Activity Questionnaire (IPAQ). As variáveis independentes do estudo são sexo, idade, raça/cor da pele, classe econômica, colegas de casa dos alunos e campo de estudo. Utilizou-se a análise de regressão multinomial para verificar a associação da variação do tempo de atividade física, em tercis, com as variáveis independentes. Resultados: A mudança geral no tempo

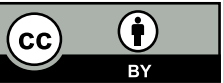


mediano de atividade física em um ano é de 90,0 minutos/semana. Os estudantes de maior nível socioeconômico mantiveram o mesmo tempo de prática de atividade física, enquanto os de outras classes apresentaram uma diminuição nesse tempo após o primeiro ano na universidade. Após os ajustes, a classe econômica mais baixa $(O R=2,85 ;$ IC95\%=1,26-6,43) e o fato de o aluno morar em uma casa compartilhada pelos alunos $(O R=2,84 ;$ IC95\%=1,26-6,38) associaram-se à redução no tempo gasto em atividade física. Conclusão: Houve diminuição do tempo gasto em atividade física entre estudantes das classes econômicas mais baixas, que viviam em uma casa compartilhada, após o primeiro ano na universidade.

Descritores: Estudantes; Universidades; Exercício Físico; Estudos Longitudinais; Fatores Socioeconômicos.

\section{RESUMEN}

Objetivo: Estimar la influencia de factores socioeconómicos en la variación del tiempo gasto por estudiantes universitarios en la práctica de actividad física después del primer año académico. Métodos: Estudio cuantitativo y longitudinal realizado entre 2015 y 2016 con 348 universitarios a jornada completa entre 16 y 25 años de la capital Mato Grosso, Brasil. El cambio del tiempo gasto con la práctica de actividad física moderada y vigorosa ha sido evaluada en minutos por semana con la versión corta del IPAQ- International Physical Activity Questionnaire. Las variables independientes fueron el sexo, la edad, la raza/el color de la piel, la clase económica, los compañeros de piso y el campo de estudio. El análisis de regresión multinomial ha sido utilizado para verificar la asociación de la variación del tiempo de actividad física en terciles y las variables independientes. Resultados: El cambio total del tiempo mediano de la actividad física en un año ha sido de -90.0 minutos/semana, los estudiantes con estatus socioeconómico más alto mantuvieron el mismo tiempo de práctica de actividad física mientras aquellos de otras clases socioeconómicas presentaron una reducción en el tiempo de actividad física después del primer año en la universidad. Tras los ajustes, la clase económica más baja $(\mathrm{OR}=2,85 ; 95 \% \mathrm{Cl}=1,26-6,43)$ y el hecho de vivir en casa compartida con estudiantes $(\mathrm{OR}=2,84 ; 95 \% \mathrm{Cl}=1,26-6,38)$ se asoció con la reducción del tiempo gasto con la actividad física. Conclusión: Hubo una reducción del tiempo gasto con la actividad física entre los estudiantes de clases económicas más bajas que vivian en casa compartida después del primer año en la universidad.

Descriptores: Estudiantes; Universidades; Ejercicio Físico; Estudios Longitudinales; Factores Socioeconómicos.

\section{INTRODUCTION}

Physical inactivity is one the main modifiable risk factors for Noncommunicable Diseases (NCDs) along with tobacco use, harmful use of alcohol and unhealthy diet ${ }^{(1)}$. In Brazil, regular physical activity was included in the National Health Promotion Program as one of its priority axes since it is directly related to health issues, mainly disease prevention ${ }^{(2,3)}$. Thus, the benefits of regular physical activity are many, with emphasis on weight control, reduction of blood pressure, and prevention of cardiovascular diseases, cancer, and diabetes ${ }^{(1)}$.

Researchers assessed the prevalence of physical inactivity in 122 countries in a systematic review and found that $31 \%$ of the population did not follow the recommendation for at least 150 minutes per week of moderate or vigorous physical activity ${ }^{(4)}$. In Brazil, according to data from a national household-based survey, the prevalence rate of insufficient physical activity is even higher $(46 \%)^{(5)}$.

A high prevalence of insufficient physical activity has been found in all age groups, and university students are one of the population groups that are vulnerable to this risky behavior because of biological, social and psychological changes resulting from the end of adolescence and admission to university. The transition between high school and university can lead to social, emotional, and even cultural changes arising from exposure to new social contacts, intense study routine and, especially, living away from home - which is very common at this stage. All of these factors may lead to the adoption of unhealthy behaviors, such as altered eating habits, increased alcohol consumption, smoking experimentation, and decreased physical activity ${ }^{(5-7)}$.

Studies that evaluated changes in lifestyle-related behaviors that occurred with university admission found a decrease in physical activity ${ }^{(7,8)}$, but none of them assessed the factors that could be associated with these changes. However, systematic reviews ${ }^{(9,10)}$ of cross-sectional studies conducted with university students showed an inverse association between physical activity and socioeconomic status.

Socioeconomic status is associated with many health problems and has an impact on risk factors, including physical inactivity ${ }^{(11)}$. However, little is known about the influence of socioeconomic factors on the change in physical activity patterns among university students, who are mostly young adults exposed to lifestyle-related risky behaviors that can be initiated, or even intensified, after admission to university ${ }^{(12,13)}$.

Therefore, the aim of this study was to estimate the influence of socioeconomic factors on the variation in time spent by university students on physical activity after the first academic year. 


\section{METHODS}

This is a follow-up study of students from a federal university in Midwestern Brazil assessed in a study titled "Longitudinal Study of the Lifestyle and Health of University Students" (the ELESEU study). This is a census-based study of all university students enrolled in 21 full-time undergraduate degree programs.

Students who reported having already taken another university course, students who had any physical disability that limited anthropometric measurement, and pregnant and lactating women were excluded from the study. Further details of the ELESEU study have been published elsewhere ${ }^{(14)}$.

A self-administered questionnaire was used to collect data. The questionnaire addressed baseline sociodemographic, economic and lifestyle information which will be described below. The data were collected in the first academic term of 2015 and follow-up data were obtained after 13 months, that is, in the first half of 2016. This time interval until follow-up allowed to evaluate the changes in physical activity during the first year of undergraduate programs at the university. Students who were not present at the time of data collection were contacted up to six times and invited to participate in the study.

In all, 812 students were enrolled in the degree programs that were evaluated at baseline. A total of 81 of these students dropped out of the program before the start of data collection and 132 did not meet the eligibility criteria. Thus, 599 students were eligible for the study. Of these, $58(9.7 \%)$ were not found during the data collection period and 46 $(7.7 \%)$ refused to participate. Hence, 495 (82.6\% of the eligible ones) students were interviewed in the first academic term of 2015. At follow-up in the first term of 2016, 51 students (10.3\%) dropped out of the program, 23 (4.6\%) stopped attending classes, $13(2.6 \%)$ transferred to a part-time program, $33(6.7 \%)$ were not found, and $27(5.4 \%)$ refused to participate in the study. The follow-up rate was $70.3 \%$, with a total of 348 university students examined (Figure 1).

Physical activity, the dependent variable of the study, was assessed using the short version of the International Physical Activity Questionnaire (IPAQ) validated for the Brazilian young adult population. This questionnaire estimates the time (in minutes) spent weekly on walking and moderate and vigorous physical activity ${ }^{(15)}$.

Time spent on physical activity was estimated as the sum of the time, in minutes, spent on moderate and vigorous physical activity in one week, with that last category is multiplied by two ${ }^{(16)}$.

Changes in time spent on physical activity were analyzed considering the variation in time spent on moderate and vigorous physical activity (minutes per week) within the period of one academic year, which was calculated as the difference between the time reported in the first academic term of 2016 and the time reported for the period prior to university admission.

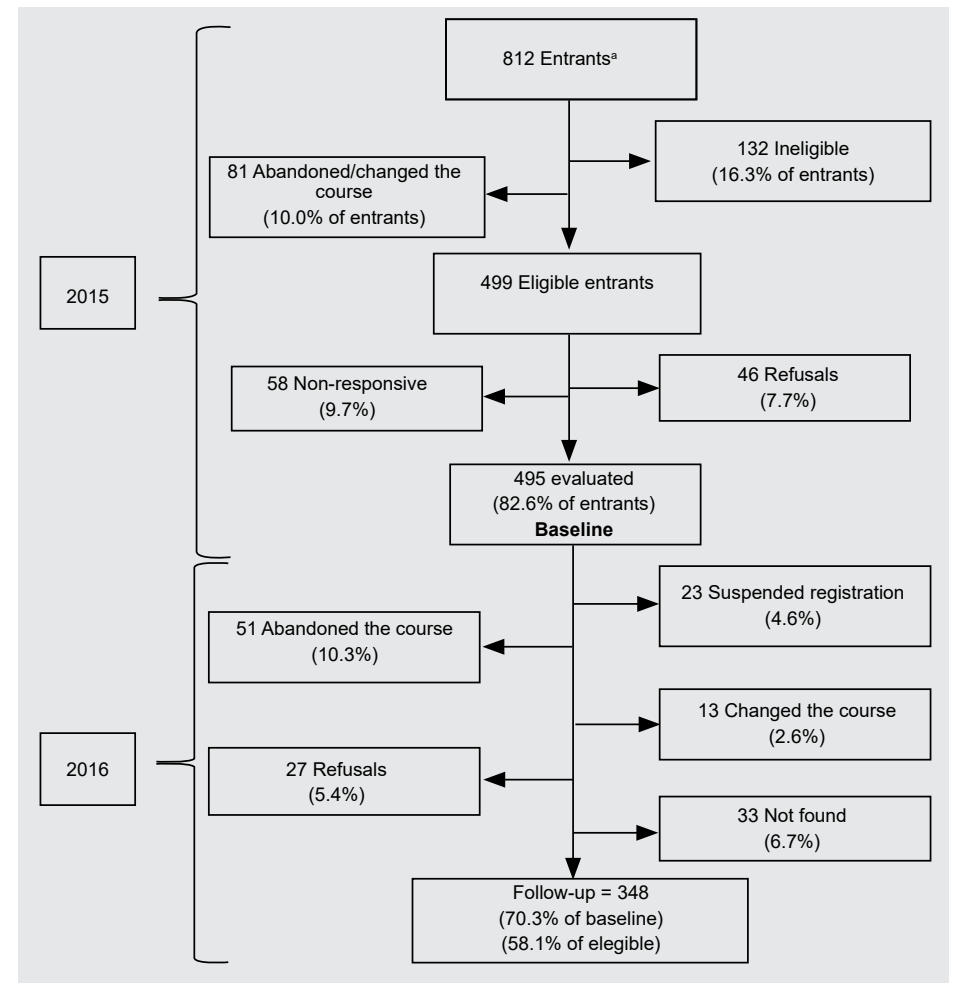

Figure 1 - Flowchart of university students assessed in 2015 and 2016. Cuiabá, Mato Grosso, Brazil, 2015-2016.

a Registered at the beginning of the term 2015-1 in full-time courses at the Federal University of Mato Grosso. Cuiabá, Mato Grosso, Brazil. 
Negative variations indicate that students decreased time spent on physical activity, while positive results show an increase in that time over the course of a year. Maintenance of time spent on physical activity during one year was represented by a value of zero. For the analyses conducted in this study, the variation in time dedicated to physical activity after the first year at university was categorized into tertiles of distribution.

Sociodemographic data collected at baseline (first academic term of 2015) were considered exposure variables. The following sociodemographic variables were evaluated: sex (men/women), age (measured as full years and categorized into three groups: 16 and 17 years, 18 and 19 years, and $\geq 20$ years) and race/skin color (White, Black and Mixed-race/Yellow/Indigenous). Such variables were analyzed in previous studies on the subject( ${ }^{(7,8)}$.

The economic factor assessed was the family socioeconomic class based on the Brazilian Criteria established by the Brazilian Association of Research Companies ${ }^{(17)}$. This criterion covers the estimation of the number of household appliances, cars and paid maids, the level of education of the head of the household, and access to public services such as piped water and paved street ${ }^{(17)}$. Based on this criterion, university students were categorized into 6 socioeconomic classes (A, B1, B2, C1, C2, D-E), with class A being the highest and class D-E being the lowest. For analysis in the present study, three categories were considered: $A, B$, and C/D/E.

The fields of the undergraduate programs were categorized into health, which included nursing, nutrition, and medicine programs, and other for other programs. Another variable analyzed was housing status at the time of the study, whether with parents, alone or in a shared house/other.

Double data entry was performed using Epi Info 7, and data consistency analysis was performed to check possible typographical errors. The dependent variable was tested for distribution by the Kolmogorov-Smirnov test. In the bivariate analysis, the Mann Whitney, Kruskal-Wallis, and Wilcoxon paired tests were used to check for associations between change in physical activity and the independent variables. The variables with a $p$ value of $<0.2$ in the bivariate analysis were included in the mutually adjusted multinomial regression model with the dependent variable classified into tertiles of distribution.

Only the variables that maintained an association at the significance level of $5 \%$ remained in the multinomial regression model. In order to check if housing status was associated with the students' socioeconomic class, an additional analysis was performed using the Chi-squared test to check for significant differences. The analyses were performed on SPSS 17.0 for Windows.

The research was approved by the Research Ethics Committee of the Júlio Muller University Hospital of the Federal University of Mato Grosso (Approval No. 1006/048). The students who agreed to participate in the study signed an Informed Consent Form before data collection.

\section{RESULTS}

At follow-up, 348 students were interviewed, of whom $51.4 \%(n=179)$ were men, $53.2 \%(n=185)$ were aged 18 and 19 years, approximately half $(n=176)$ belonged to socioeconomic class $B$, and about $70 \%(n=242)$ lived with their parents, as shown in Table I.

The median time spent on moderate and vigorous physical activity was 480 minutes (IQR=120; 955minutes) before admission to university and 240 minutes (IQR=0; 630minutes), p-value $<0.01$ for Wilcoxon's test.

After the first year at the university, a higher median time spent on physical activity was observed in men compared to women (360 minutes/week vs 180 minutes/week, $p=0.04$ ). Health care students presented lower median values for physical activity when compared to students in other programs, both before $(p=0.005)$ and after $(p=0.004)$ admission. A decrease in time spent by students on physical activity was associated with almost all categories of variables, but this decrease was not significant in students of higher socioeconomic status.

The overall change in median physical activity time in one year was -90 minutes per week. Although there were no significant differences in median values for time spent on physical activity according to socioeconomic status at baseline and at follow-up, the students in the socioeconomic class A maintained the same physical activity time, while those in classes $B$ and $C / D / E$ showed a decrease in time, with median values of -90 minutes/week and -270 minutes/week, respectively, as shown in Table II. Students living in shared houses also presented a more pronounced decrease in median physical activity time compared to those who lived with their parents and those who lived alone.

The first tertile of distribution was composed of students who presented the most significant decrease in time spent on physical activity (from -2820 to -350 minutes per week), whereas in the second tertile the variation in this time was less than - 350 to -0.1 minutes. The third tertile showed a variation from 0 to 2760 minutes per week and was represented by students who maintained or increased physical activity during the first year at university. The 
proportion of students in socioeconomic classes $C / D / E$ categorized in the first tertile was higher (46.4\%) than that in socioeconomic class A $(21.1 \% ; p<0.01)$. There was a higher proportion of individuals categorized in the first tertile of variation in physical activity (54.7\%) among students living in a shared house compared to those living with their parents $(29.3 \% ; p<0.01)$.

Table I - Distribution of students (\%) and median and interquartile range (IQR) for time spent on physical activity in the year before admission and after the first academic year according to sociodemographic and economic characteristics. Cuiabá, Mato Grosso, Brazil, 2015-2016.

\begin{tabular}{|c|c|c|c|c|c|c|c|}
\hline & \multicolumn{2}{|c|}{ Overall } & \multicolumn{2}{|c|}{$\begin{array}{l}\text { Before admission }(\mathrm{min} / \\
\text { week) }\end{array}$} & \multicolumn{2}{|c|}{$\begin{array}{l}\text { After admission } \\
\text { (min/week) }\end{array}$} & \multirow[t]{2}{*}{ p-value } \\
\hline & $\mathbf{n}$ & (\%) & Median & (IQR) & Median & (IQR) & \\
\hline TOTAL & 348 & $(100)$ & 480 & $(120 ; 955)$ & 240 & $(0 ; 630)$ & $<0.01$ \\
\hline \multicolumn{8}{|l|}{ Gender } \\
\hline Men & 179 & $(51.4)$ & 480 & $(120 ; 1140)$ & 360 & $(30 ; 720)$ & $<0.01$ \\
\hline Women & 169 & $(48.6)$ & 480 & $(105 ; 840)$ & 180 & $(0 ; 480)$ & $<0.01$ \\
\hline$p$-value ${ }^{a}$ & & & \multicolumn{2}{|c|}{0.29} & \multicolumn{2}{|c|}{0.04} & \\
\hline \multicolumn{8}{|l|}{ Age group (years) } \\
\hline $16-17$ & 93 & $(26.7)$ & 420 & $(145 ; 915)$ & 180 & $(0 ; 585)$ & $<0.01$ \\
\hline $18-19$ & 185 & $(53.2)$ & 480 & $(90 ; 900)$ & 240 & $(3.75 ; 640)$ & $<0.01$ \\
\hline$\geq 20$ & 70 & $(20.1)$ & 565 & $(97.5 ; 1080)$ & 260 & $(0 ; 690)$ & $<0.01$ \\
\hline$p$-value ${ }^{a}$ & & & \multicolumn{2}{|c|}{0.70} & \multicolumn{2}{|c|}{0.73} & \\
\hline \multicolumn{8}{|l|}{ Skin color/race } \\
\hline White & 144 & 41.4 & 360 & $(90 ; 900)$ & 240 & $(3.75 ; 600)$ & 0.001 \\
\hline Black & 39 & 11.2 & 660 & $(240 ; 1080)$ & 480 & $(180 ; 840$ & 0.097 \\
\hline Mixed-race/Yellow/Indigenous & 164 & 47.1 & 480 & $(112.5 ; 1020)$ & 180 & $(00 ; 587.5)$ & $<0.01$ \\
\hline$p$-value & & & \multicolumn{2}{|c|}{0.12} & \multicolumn{2}{|c|}{0.03} & \\
\hline \multicolumn{8}{|l|}{ Economic class $^{c}$} \\
\hline$A$ & 71 & $(20.4)$ & 360 & $(90 ; 900)$ & 240 & $(0 ; 960)$ & 0.899 \\
\hline B & 176 & $(50.6)$ & 390 & $(120 ; 900)$ & 240 & $(0 ; 600)$ & $<0.01$ \\
\hline $\mathrm{C}, \mathrm{D}$ and $\mathrm{E}$ & 98 & $(28.2)$ & 540 & $(97.5 ; 1275)$ & 280 & $(0 ; 620)$ & $<0.01$ \\
\hline$p$-value ${ }^{a}$ & & & \multicolumn{2}{|c|}{0.17} & \multicolumn{2}{|c|}{0.69} & \\
\hline \multicolumn{8}{|l|}{ Housing status } \\
\hline With parents & 242 & $(69.5)$ & 410 & $(87.5 ; 900)$ & 240 & $(0 ; 640)$ & $<0.01$ \\
\hline Alone & 53 & $(15.2)$ & 360 & $(120.915)$ & 220 & $(60 ; 600)$ & $<0.01$ \\
\hline Shared house & 53 & $(15.2)$ & 600 & $(270 ; 1200)$ & 360 & $(65 ; 602.5)$ & $<0.01$ \\
\hline$p$-value & & & \multicolumn{2}{|c|}{0.07} & \multicolumn{2}{|c|}{0.812} & \\
\hline \multicolumn{8}{|c|}{ Fields of the undergraduate program } \\
\hline Health & 62 & $(17.8)$ & 255 & $(0 ; 675)$ & 102 & $(0 ; 427.5)$ & 0.02 \\
\hline Others & 286 & $(82.2)$ & 510 & $(120 ; 1027)$ & 300 & $(35 ; 660)$ & $<0.01$ \\
\hline$p$-value ${ }^{a}$ & & & \multicolumn{2}{|c|}{$<0.01$} & \multicolumn{2}{|c|}{$<0.01$} & \\
\hline
\end{tabular}

ap-value associated with the Mann-Whitney U-Test or Kruskal-Wallis for independent samples; ${ }^{\mathrm{b}}$ Wilcoxon's test; 'According to the Brazilian Association of Research Companies (ABEP, 2015). Bold: significance level of $5 \%$ 
Table II - Median and Interquartile Interval (IQR) of the variation in time spent on physical activity in the year before admission and after the first academic year (minutes per week) according to sociodemographic and economic characteristics. Cuiabá, Mato Grosso, Brazil, 2015-2016.

\begin{tabular}{|c|c|c|c|c|c|}
\hline & \multirow{2}{*}{\multicolumn{2}{|c|}{$\begin{array}{c}\text { Variation in physical activity } \\
\text { time }(2015-2016) \\
\text { Minutes/week }\end{array}$}} & \multicolumn{3}{|c|}{$\begin{array}{l}(2015-2016) \\
\text { Minutes/week }\end{array}$} \\
\hline & & & \multirow{2}{*}{$\begin{array}{c}1^{\text {st }} \text { tertile } \\
\leq-350.0 \\
n(\%)\end{array}$} & \multirow{2}{*}{$\begin{array}{c}2^{\text {nd }} \text { tertile } \\
-350.0 ;-0.01 \\
n(\%) \\
\end{array}$} & \multirow{2}{*}{$\begin{array}{c}3^{\text {rd }} \text { tertile } \\
\geq 0.0 \\
\mathrm{n}(\%)\end{array}$} \\
\hline & Median & (IQR) & & & \\
\hline TOTAL & -90.0 & $(-510 ; 150)$ & $115(33.0)$ & $125(35.9)$ & 108(31.0) \\
\hline \multicolumn{6}{|l|}{ Gender } \\
\hline Men & -80.0 & $(-460 ; 190)$ & $55(30.7)$ & $61(34.1)$ & $63(35.2)$ \\
\hline Women & -120.0 & $(-540 ; 85)$ & $60(35.7)$ & $63(37.5)$ & $45(26.8)$ \\
\hline$p$-value ${ }^{a}$ & \multicolumn{2}{|c|}{0.17} & \multicolumn{3}{|c|}{0.23} \\
\hline \multicolumn{6}{|l|}{ Age group (years) } \\
\hline $16-17$ & -150.0 & $(-472.5 ; 65)$ & $28(30.1)$ & $40(43.0)$ & $25(26.9)$ \\
\hline $18-19$ & -60.0 & $(-502.5 ; 180)$ & $55(29.9)$ & $68(37.0)$ & $61(33.2)$ \\
\hline$\geq 20$ & -250.0 & $(-605 ; 187.5)$ & $32(45.7)$ & $16(22.0)$ & $22(31.4)$ \\
\hline$p$-value & \multicolumn{2}{|c|}{0.37} & \multicolumn{3}{|c|}{0.05} \\
\hline \multicolumn{6}{|l|}{ Skin color/race } \\
\hline White & -90.0 & $(-420 ; 131.2)$ & $42(29.2)$ & $60(41.7)$ & $42(29.2)$ \\
\hline Black & -300.0 & $(-750 ; 360)$ & $17(43.6)$ & $8(20.5)$ & $14(35.9)$ \\
\hline Mixed-race/Yellow/Indigenous & -120.0 & $(-540 ; 142)$ & $56(34.1)$ & $56(34.1)$ & $52(31.7)$ \\
\hline$p$-value & \multicolumn{2}{|c|}{0.83} & \multicolumn{3}{|c|}{0.16} \\
\hline \multicolumn{6}{|l|}{ 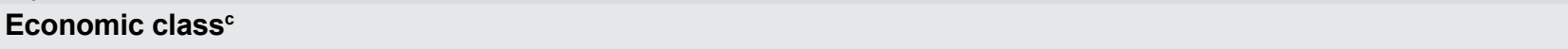 } \\
\hline A & 0.000 & $(-300 ; 300)$ & $15(21.1)$ & $26(36.6)$ & $30(42.3)$ \\
\hline $\mathrm{B}$ & -90.0 & $(-477.5 ; 131.25)$ & $54(30.7)$ & $70(39.8)$ & $52(29.5)$ \\
\hline $\mathrm{C}, \mathrm{D}$ and $\mathrm{E}$ & -270.0 & $(-780 ; 25)$ & $45(46.4)$ & $27(27.8)$ & $25(25.8)$ \\
\hline$p$-value & \multicolumn{2}{|c|}{$<0.01$} & \multicolumn{3}{|c|}{$<0.01$} \\
\hline \multicolumn{6}{|l|}{ Housing status } \\
\hline With parents & -60.0 & $(-420 ; 180)$ & $71(29.3)$ & $85(35.1)$ & $86(35.5)$ \\
\hline Alone & -125.0 & $(-467.5 ; 0)$ & $15(28.8)$ & $25(48.1)$ & $12(23.1)$ \\
\hline Shared houses & -405.0 & $(-780 ; 0)$ & $29(54.7)$ & $14(26.4)$ & $10(18.9)$ \\
\hline$p$-value ${ }^{a}$ & \multicolumn{2}{|c|}{0.01} & \multicolumn{3}{|c|}{$<0.01$} \\
\hline \multicolumn{6}{|c|}{ Fields of the undergraduate program } \\
\hline Health & -72.5 & $(-277.5 ; 75)$ & $14(22.6)$ & $31(50.0)$ & $17(27.4)$ \\
\hline Others & -120.0 & $(-540 ; 180)$ & $101(35.4)$ & $93(32.6)$ & $91(31.9)$ \\
\hline$p$-value ${ }^{a}$ & \multicolumn{2}{|c|}{0.50} & \multicolumn{3}{|c|}{0.03} \\
\hline
\end{tabular}

ap-value associated with the Mann-Whitney U-Test or Kruskal-Wallis for independent samples and Chi-squared test for categorical variables; ' According to the Brazilian Association of Research Companies (ABEP, 2015). Bold: significance level of $5 \%$

An additional analysis of the distribution of students according to socioeconomic class and demographic variables was conducted and is shown in Table III. A higher proportion of university students who reported living in a shared house belonged to socioeconomic classes C/D/E compared to other higher classes $(p<0.001)$.

Table III - Distribution of economic classes according to housing condition of the university students assessed in 2015 and 2016. Cuiabá, Mato Grosso, Brazil, 2015-2016.

\begin{tabular}{|c|c|c|c|c|c|c|c|}
\hline & \multicolumn{6}{|c|}{ Economic class } & \multirow{3}{*}{ p-value } \\
\hline & \multicolumn{2}{|c|}{$\mathbf{A}$} & \multicolumn{2}{|c|}{ B } & \multicolumn{2}{|c|}{ C/D/E } & \\
\hline & $\mathbf{n}$ & $(\%)$ & $\mathbf{n}$ & $(\%)$ & $n$ & $(\%)$ & \\
\hline \multicolumn{8}{|l|}{ Housing status } \\
\hline With parentes & 54 & 22.5 & 133 & 55.4 & 53 & 22.1 & \\
\hline Alone & 14 & 26.4 & 22 & 41.5 & 17 & 32.1 & $<0.01$ \\
\hline Shared houses & 03 & 5.8 & 21 & 40.4 & 28 & 53.8 & \\
\hline
\end{tabular}

${ }^{a}$ According to the Brazilian Association of Research Companies (ABEP, 2015).

${ }^{b} \mathrm{p}$-value of Qui-squared test. Bold: significance level of $5 \%$ 
After the adjusted analysis, only the socioeconomic class $C / D / E$ and living in a shared house remained associated with the decrease in time spent on physical activity during the first year of university $(\mathrm{OR}=2.85$ and $\mathrm{OR}=2.84$, respectively). Living alone was associated with the second tertile $(\mathrm{OR}=2.20)$, as shown in Table IV.

Table IV - Crude and adjusted Odds Ratio and $95 \%$ confidence interval $(95 \% \mathrm{Cl})$ of the association of socioeconomic variables with the variation in time spent on physical activity after one year at university. Cuiabá, Mato Grosso, Brazil, 2015-2016.

\begin{tabular}{|c|c|c|c|c|c|c|c|c|}
\hline & \multicolumn{4}{|c|}{$\begin{array}{l}\text { Variation in physical activity time }(\mathrm{min} / \\
\text { week) in tertile }\end{array}$} & \multicolumn{4}{|c|}{$\begin{array}{l}\text { Variation in physical activity time }(\mathrm{min} / \\
\text { week) in tertile }\end{array}$} \\
\hline & \multicolumn{2}{|c|}{$1^{\text {st }}$ tertile } & \multicolumn{2}{|c|}{$2^{\text {nd }}$ tertile } & \multicolumn{2}{|c|}{$1^{\text {st }}$ tertile } & \multicolumn{2}{|c|}{$2^{\text {nd }}$ tertile } \\
\hline & \multicolumn{4}{|c|}{ Odds Ratio $(95 \% \mathrm{Cl})$} & \multicolumn{4}{|c|}{ Adjusted Odds Ratio (95\%Cl)' } \\
\hline \multicolumn{9}{|l|}{ Gender } \\
\hline Men & 1 & - & 1 & - & & & & \\
\hline Women & 1.53 & $(0.90-2.59)$ & 1.47 & $(0.87-2.47)$ & & & & \\
\hline \multicolumn{9}{|l|}{ Age group (years) } \\
\hline $16-17$ & 1 & - & 1 & - & & & & \\
\hline $18-19$ & 0.80 & $(0.42-1.54)$ & 0.71 & $(0.38-1.30)$ & & & & \\
\hline$\geq 20$ & 1.29 & $(0.60-2.79)$ & 0.45 & $(0.20-1.03)$ & & & & \\
\hline \multicolumn{9}{|l|}{ Skin color/race } \\
\hline White & 1 & - & 1 & - & & & & \\
\hline Black & 1.21 & $(0.53 ; 2.77)$ & 0.40 & $(0.15 ; 1.04)$ & & & & \\
\hline Mixed-race/Yellow/Indigenous & 1.08 & $(0.61 ; 1.91)$ & 0.75 & $(0.44 ; 1.30)$ & & & & \\
\hline \multicolumn{9}{|l|}{ Economic class } \\
\hline A & 1 & - & 1 & - & 1 & - & 1 & - \\
\hline B & 2.08 & $(1.00-4.30)$ & 1.55 & $(0.82-2.93)$ & 1.97 & $(0.94-4.11)$ & 1.63 & $(0.85-3.10)$ \\
\hline $\mathrm{C}, \mathrm{D}$ and $\mathrm{E}$ & 3.60 & $(1.63-7.93)$ & 1.29 & $(0.69-2.74)$ & 2.85 & $(1.26-6.43)$ & 1.20 & $(0.56-2.63)$ \\
\hline \multicolumn{9}{|l|}{ Housing status } \\
\hline With parents & 1 & - & 1 & - & 1 & - & 1 & - \\
\hline Alone & 1.51 & $(0.66-3.44)$ & 2.19 & $(1.04-4.63)$ & 1.51 & $(0.66-3.49)$ & 2.20 & $(1.03-4.69)$ \\
\hline Shared house & 3.51 & $(1.60-7.70)$ & 1.42 & $(0.60-3.36)$ & 2.84 & $(1.26-6.38)$ & 1.29 & $(0.52-3.18)$ \\
\hline \multicolumn{9}{|c|}{ Fields of the undergraduate program } \\
\hline Health & 1 & - & 1 & - & & & & \\
\hline Others & 1.35 & $(0.63-2.89)$ & 0,57 & $(0.29-1.10)$ & & & & \\
\hline
\end{tabular}

a Mutually adjusted model. Bold: significance level of $5 \%$

\section{DISCUSSION}

In the present study, socioeconomic factors were associated with change in time spent on physical activity among university students, and those who belonged to the lower socioeconomic classes (C/D/E) showed a pronounced decrease in time spent on moderate and vigorous physical activity in comparison to students in higher socioeconomic classes. That latter were able to maintain or increase physical activity during the first year at university. Students living in shared houses had a increased chances of decreasing their physical activity time compared to students living with their parents. Living alone also meant a greater chance of decreased physical activity among students compared to students living with their parents.

These findings broaden the knowledge about important risk factors related to the lifestyle of university students, as few studies have evaluated the factors associated with changes in physical activity after admission to university ${ }^{(7,8,18)}$. After reviewing the literature, we did not find any study that assessed the association of sociodemographic and economic factors with potential changes in physical activity after admission to university.

One of the possible explanations for the decrease in physical activity among university students is lack of time caused by the increased time spent on obligations, which leads to a decrease in time available for leisure ${ }^{(19)}$. In a cross-sectional study that assessed the barriers to physical activity, lack of time was cited as the main reason by more than $50 \%$ of university students ${ }^{(19)}$. Another reason for the decrease in physical activity levels may be the exclusion of physical education as a compulsory subject from the university curricula ${ }^{(20)}$.

Although these barriers have not been investigated in the present study, it should be noted that the beginning of a full-time university program can be marked by changes in students' routine: they spend more time on campus 
and increase the number of study hours at home. Therefore, they often cannot maintain or increase the amount of physical activity.

Low levels of physical activity were observed among students of low socioeconomic status ${ }^{(12)}$. Other studies showed that the lower the socioeconomic status, the higher the risk of unhealthy behaviors such as physical inactivity in adolescents and adults ${ }^{(20-22)}$.

Lower socioeconomic status may be associated with unequal opportunities for access to physical activity promoting environments ${ }^{(23,24)}$. Another study carried out with data from Brazil's 2015 National Household Sample Survey also found a positive association between physical activity and income ${ }^{(25)}$. The results of the present study reinforce the negative influence of lower socioeconomic status on a behavior known to be beneficial for health.

In that regard, and aiming to improve access to physical activity among people of low socioeconomic status, the National Health Promotion Policy (Política Nacional de Promoção da Saúde - PNPS) was created in 2006 and listed some priority actions, including physical activity, with the aim of encouraging improvements in public spaces through games, dances and other activities to encourage physical activity(3,4).

Few longitudinal studies have assessed the influence of socioeconomic factors on changes in physical activity. One example is the study that investigated British adolescents for a five-year period and found a tendency for decreased physical activity in adolescents of low socioeconomic status ${ }^{(26)}$. Furthermore, it should be noted that most studies on physical activity among university students use a cross-sectional design and hence cannot assess changes to this behavior in the same individuals. A systematic review of physical activity among university students found that all the studies used a cross-sectional design ${ }^{(27)}$.

The relationship between socioeconomic status and physical activity among university students is also found in studies that compared the prevalence of physical inactivity across countries with different cultural contexts and levels of development. In a study of university students from 23 countries, researchers found that the prevalence of physical inactivity in leisure time was higher in developing countries $(44 \%)$ compared to European countries and the United States $(23 \%)^{(9)}$. Similarly, university students from middle and high-income countries were more physically active than those from low-income countries in a study of university students from 24 universities ${ }^{(10)}$.

In analyzing leisure-time physical activity, one study found that students belonging to higher socioeconomic strata exhibited higher prevalence rates of physical activity $\left(>150\right.$ minutes/week) ${ }^{(28)}$. However, the analysis of physical activity while walking or cycling showed that those students were less active compared to students of lower socioeconomic status. Nevertheless, the sum of these two domains did not remain associated with socioeconomic status, thus showing that divergent associations can be found depending on the domain of physical activity that is being analyzed.

Living with parents may suggest that university students have more time to engage in leisure-time physical activity, while students living in shared houses spend more time on household chores and dietary care and also need to afford their living and food expenses ${ }^{(29)}$ In the present study, this finding could be explained by the fact that more than $50 \%$ of the university students living in shared houses belonged to the lower socioeconomic classes. However, both factors remained associated even after mutual control in the multivariate analysis.

The analysis of moderate and vigorous physical activity in minutes per week showed a shorter time among women compared to men at follow-up (one year after having started their university program). This difference between genders were consistent with previous studies of university students and other age groups $\mathbf{s}^{(9,30,31)}$.

When physical activity in minutes per week was analyzed before admission to university and after the first year at university, it was observed that healthcare university students presented shorter physical activity time compared to university students in other fields. A study assessing the prevalence of leisure-time physical activity among healthcare students found a higher prevalence of sufficient physical activity in leisure time. However, when analyzing total physical activity (leisure and walking or cycling), there was no significant difference between the undergraduate programs ${ }^{(29)}$. It should be noted that future healthcare professionals should develop healthy habits, including physical activity, because these professionals will be responsible for encouraging future generations.

One should take into account that it is difficult to compare the results of this study with other studies that assessed physical activity among university students because there are methodological differences in the assessment of physical activity level, as observed in one study ${ }^{(18)}$ that assessed changes in physical activity using the extended version of the IPAQ with physical education students.

One of the limitations of the present study is that the criterion used to assess socioeconomic level, namely the Brazil Criterion (Critério Brasil), was not developed for health-related research. However, it has been used in epidemiological studies and is considered useful in assessing the socioeconomic status of families ${ }^{(32)}$. In addition, 
physical activity was assessed in the present study by a subjective method, but these types of instruments are being widely used in epidemiological studies ${ }^{(33)}$.

One strength of the present study is its longitudinal design, since most of the studies that assessed physical activity among university students had a cross-sectional design and those that assessed changes in physical activity did not investigate the factors associated with behavior change. It is also worth mentioning the high follow-up rate, which was $70.3 \%$. This is a novel study that assessed changes in time spent on physical activity among students after admission to university and the associated sociodemographic and economic factors.

Considering that socioeconomic factors can influence moderate and vigorous physical activity among university students in the short and long term, there should be greater encouragement to physical activity through the production and dissemination of information about the benefits of such activity in the university environment. Availability of spaces for physical activity and the inclusion of physical activity as a module or extension project could encourage it, mainly among full-time students and those who depend on aid from current programs and policies in universities. Such measures become of paramount importance in the university environment because inappropriate habits in this phase of life can persist in adult life and increase the occurrence of non-communicable diseases ${ }^{(6,34,35)}$.

\section{CONCLUSION}

There was a decrease in time spent on moderate and vigorous physical activity among university students, especially among those who belonged to the lower socioeconomic classes and who lived in a shared house. The first years of university is an important time to support individuals in preventing a decrease in physical activity, mainly among those students of lower socioeconomic status.

\section{CONFLICTS OF INTEREST}

There were no conflicts of interest in the development of this study.

\section{CONTRIBUTIONS}

Suellem Regina Chamberllem and Ana Paula Muraro contributed to the study conception and design; acquisition, analysis and interpretation of data; and manuscript writing. Márcia Gonçalves Ferreira and Paulo Rogério Melo Rodrigues contributed to the study conception and design; and manuscript writing. Patrícia Simone Nogueira and Rosangela Alves Pereira contributed to manuscript writing.

\section{ACKNOWLEDGMENTS}

The authors thank the volunteers who participated in the study and the field epidemiology team for assisting with data collection and management.

\section{FINANCIAL SUPPORT}

This study was partly funded by the Coordination for the Improvement of Higher Education Personnel (Coordenação de Aperfeiçoamento de Pessoal de Nível Superior - CAPES) - Award No. 001.

\section{REFERENCES}

1. World Health Organization. Physical activity [Internet]. 2018 [accessed on 2020 May 10]. Available from: https://www.who.int/news-room/fact-sheets/detail/physical-activity

2. Ministério da Saúde (BR), Secretaria de Vigilância à Saúde, Secretaria de Atenção à Saúde. Política Nacional de Promoção da Saúde: PNaPS: revisão da Portaria MS/GM no 687, de 30 de março de 2006. Brasília: Ministério da Saúde; 2014.

3. Malta DC, Silva MMA, Albuquerque GM, Lima CM, Cavalcante T, Jaime PC, et al. A implementação das prioridades da Política Nacional de Promoção da Saúde, um balanço, 2006 a 2014. Cienc Saude Colet. 2014;19(11):4301-12.

4. Hallal PC, Anderson LB, Bull FC, Guthold R, Haskell W, Ekelund V, et al. Global Physical activity levels: surveillance progress, pitfalls and prospect. Lancet. 2012;380(9838):247-57. 
5. Silva NJ, Oliveira-Júnior AA, Raposo OFF, Silva DG, Mendes-Netto RS, Barbosa KBF. Frequency of healthy eating habits among students of a public university in Northeastern Brazil. Rev Bras Promoç Saude. 2016;29(2):277-34.

6. Lopes PD, Rezende AAA, Calábria LK. Risk factors for non-communicable diseases in university students. Rev Bras Promoç Saude. 2017;30(4):1-11.

7. Deforche B, Dyck DV, Deliens T, Bourdeaudhuij ID. Changes in weight, physical activity, sedentary behaviour and dietary intake during the transition to higher education: a prospective study. Int J Behav B Nutr Phys. 2015;12:1-10.

8. Winpenny EM, Smith M, Penney T,_Foubister C, Guagliano JM, Love R, et al. Changes in physical activity, diet, and body weight across the education and employment transitions of early adulthood: A systematic review and meta-analysis. Obes Rev. 2020;21(4):e12962.

9. Haase J, Phil ASD, Sallis JF, Wardle J. Leisure-time physical activity in university student from 23 countries: associattions with healt beliefs, risk awareneses and national economic development. Prev Med. 2004;39(1):182-90.

10. Pengpid S, Peltzer K, Kassean HK, Tsala JPT, Sychariun V. Physical inactivity and associated factors among university student in 23 low-middle-and high- income countries. Int J Public Health. 2015;60:539-49.

11. Kipping RR, Smith M, Heron J, Hickman M, Campbell R. Multiple risk behaviour in adolescence and socioeconomic status: findings from a UK birth cohort. Eur J Public Health. 2015;25(1):44-9.

12. Beaudry KM, Ludwa IA, Thomas AM, Ward WE, Falk B, Josse AR. First-year university is associated with greater body weight, body composition and adverse dietary changes in males than females. PLoS One. 2019;14(7):e0218554.

13. Puelo FG, Betran YH. Factores sociodemográficos $Y$ motivacionales asociados a la actividad fisica en estudiantes universitarios. Rev Med Chil. 2015;143:1411-8.

14. Nogueira PS, Ferreira MG, Rodrigues PRM, Muraro AP, Pereira LP, Pereira RA. Longitudinal Study on Lifestyle and Health of University Students - ELESEU: design, methodological procedures and preliminary results. Cad Saude Publica. 2018;34(4):e00145917.

15. Matsudo S, Araujo T, Matsudo V, Andrade D, Andrade E, Oliveira LC, et al. International Physical Activity Questionnaire (IPAQ): a study of validity and reproducibility in Brazil. Rev Bras Ativ Fis Saude. 2001;6(2):5-18.

16. Hallal PC, Victoria CG, Wells IC, Lima RC. Physical inactivity: prevalence and associated variables in Brazilian adults. Med Sci Sports Exerc. 2003;35(11):1894-900.

17. Associação Brasileira de Empresas de Pesquisa. Critério de Classificação Econômica Brasil de 2015 [Internet]. [2016] [accessed on 2020 May 10]. Available from: http://www.abep.org/criterio-brasil

18. Leão OAA, Santos TS, Silva MC. Correlation between physical activity and sedentary behavior in students. Rev Bras Promoç Saude. 2018;31(2):1-6.

19. El-Gilany AH, Badawi K, El-Khawaga G, Awadalla N. Physical activity profile of students in Mansoura University, Egypt. East Mediterr Health J. 2011;17(8):694-702.

20. Hollis JL, Sutherland R, Williams AJ, Campbell E. A systematic review and meta-analysis of moderate-tovigorous physical activity levels in secondary school physical education lessons. Int J Behav Nutr Phys Act. 2017;14(1):52.

21. Kipping RR, Smith M, Heron J, Hickman M, Campbell R. Multiple risk behaviour in adolescence and socioeconomic status: findings from a UK birth cohort. Eur J Public Health. 2015;25(1):44-9.

22. Meader N, King K, Moe-Byrne T, Wright K, Graham H, Petticrew M, et al. A systematic review on the clustering and co-occurrence of multiple risk behaviours. BMC Public Health. 2016;16:657.

23. Loh VHY, Rachele JN, Brown WJ, Washington S, Turrell G. Neighborhood disadvantage, individual-level socioeconomic position and physical function: a cross-sectional multilevel analysis. Prev Med. 2016;89:112-20.

24. Kleszczewska D, Mazur J, Siedlecka J. Family, school and neighborhood factors moderating the relationship 
between physical activity and some aspects of mental health in adolescents. Int $\mathrm{J}$ Occup Med Environ Health. 2019;32(4):423-39.

25. Pontes SS, Silva AM, Santos LMS, Souza BVN, Oliveira BVS. Práticas de atividade física e esporte no Brasil. Rev Bras Promoç Saude. 2019;32:8406.

26. Brodersen NH, Steptoe A, Boniface DR, Wardle J. Trend in physical activity sedentary behaviour in adolescence: ethnic and socioeconomic differences. Br J Sports Med. 2007;41:140-44.

27. Sousa TF. Inatividade física em universitários brasileiros: uma revisão sistemática. Rev Bras Cienc Saude. 2011;9(29):47-55.

28. Mielke GI, Ramis TR, Habeyche EC, Oliz, MM, Tessmer MGS, Azevedo MR, et al. Atividade física e fatores associados em universitários do primeiro ano da Universidade Federal de Pelotas. Rev Bras Ativ Fis Saude. 2010;15(1):57-64.

29. Gasparotto GS, Moreira NB, Gasparotto LPR, Silva MP, Campos W. Associação entre fatores sociodemográficos e o nível de atividade física de universitários. Rev Bras Cienc Mov. 2013;21(4):30-40.

30. Mielke GI, Hallal PC, Rodrigues GBA, Szwarcwald CL, Santos FV, Malta DC. Prática de atividade física e hábito de assistir televisão entre adultos no Brasil. Epidemiol Serv Saude. 2015;24(2):277-86.

31. Sa J, Heimdal J, Sbrocco T, Seo DC, Nelson B. Overweight and Physical Inactivity Among African American Students at a Historically Black University. J Natl Med Assoc. 2016;108(1):77-85.

32. Antunes JLF. Condições socioeconômicas em saúde: discussão de dois paradigmas. Rev Saude Publica. 2008;42(3):562-7.

33. Hallal PC, Dumith SC, Bastos JP, Reichert FF, Siqueira FV, Azevedo MR. Evolução da pesquisa epidemiológica em atividade física no Brasil: revisão sistemática. Rev Saude Publica. 2007:41(3):453-460.

34. Berbigier MC, Magalhães $C R$. Educação nutricional em universitários e estratégias para promoção de saúde institucional: revisão integrativa. Rev Bras Promoç Saude. 2017:30(2):264-74.

35. Allom V, Mullan B, Cowie E, Hamilton K. Physical Activity and Transitioning to College: the Importance of Intentions and Habits. Am J Health Behav. 2016;40(2):280-90.

First author's address:

Suellem Regina Chamberllem

Departamento de Alimentos e Nutrição - Universidade Federal de Mato Grosso

Avenida Fernando Corrêa da Costa, 2367/ Bloco CCBS III

Bairro: Boa Esperança

CEP: 78060-900 - Cuiabá - MT - Brasil

E-mail: suellemnut@gmail.com

Mailing address:

Ana Paula Muraro

Instituto de Saúde Coletiva - Universidade Federal de Mato Grosso

Avenida Fernando Corrêa da Costa, 2367/ Bloco CCBS III

Bairro: Boa Esperança

CEP: 78060-900 - Cuiabá - MT - Brasil

E-mail: muraroap@gmail.com

How to cite: Chamberllem SR, Ferreira MG, Rodrigues PRM, Nogueira PS, Pereira RA, Muraro AP. Influence of sociodemographic and economic factors on physical activity among university students. Rev Bras Promoç Saúde. 2020;33:10745. 